Volume I Tahun 2021

November 2021
E-ISSN: 2808-5361 http://e-journal.fkmumj.ac.id/
Proceeding The First Muhammadiyah InternasionalPublic Health and Medicine

Conference

\title{
Impact of The Covid -19 Pandemic on Mental Health in Society
}

\author{
Any Sulistyaningsih \\ Faculty of Public Health, Muhammadiyah University of Jakarta \\ K.H. Ahmad Dahlan St, Cireundeu, Ciputat, Jakarta Selatan, 15419 \\ Email: anytya295@gmail.com
}

\begin{abstract}
Another health problem that has emerged as a result of the Covid-19 pandemic is mental health problems which if left unchecked can develop into serious health problems. The Oxford study shows that people over the age of 50 who are female, and those who are hospitalized due to the coronavirus are much more likely to suffer from brain and psychological complications, a much higher risk of dementia, a brain disorder condition, in Covid-19 survivors. 19. The research method used is descriptive qualitative research. The Covid-19 pandemic not only has an impact on physical health but also has an impact on other aspects of life such as the social and economic aspects of the community. From the results of interviews with the subject, the author indicates that individuals infected with Covid-19 experience anxiety, worry, and fear, even stress. Anxiety is not only due to the coronavirus infection but also the social environment in which they live which still discriminates against patients and their families infected with Covid-19.
\end{abstract}

Keywords: Covid-19 pandemic, Mental health 
E-ISSN: 2808-5361 http://e-journal.fkmumj.ac.id/
Proceeding The First Muhammadiyah InternasionalPublic Health and Medicine Conference

\section{INTRODUCTION}

The World Health Organization (WHO) has officially declared the Covid-19 outbreak a global pandemic. This was conveyed on Wednesday, 11/3/2020 evening. In less than three months, Covid-19 has infected more than 126,000 people in 123 countries, from Asia, Europe, the US, to South Africa. In the past two weeks, the number of cases outside China has increased thirteenfold and the number of affected countries has tripled, said WHO Director-General Dr. Tedros Adhanom Ghebreyesusus at a press conference at WHO headquarters in Geneva. (Gloria Setyvani Putri, 2020). From statistical data, it is known that the Covid-19 infection until May 08, 2021, reached 156 million people, and 92.6 million people recovered from this infection. (Covid-19 Infection Data, 2021). The President of the Republic of Indonesia through Presidential Decree No. 12 of 2020 stated that the Determination of Non-Natural Disasters for the Spread of Corona Virus Disease 2019 is a National Disaster. Statistical data on Covid -19 infections in Indonesia as of May 8, 2021, amounted to 1.7 million people and 1.55 million people have recovered from this infection. (Covid-19 Infection Data, 2021).

Common symptoms that are often experienced by patients are fever, cough, and myalgia or fatigue. Specific symptoms include coughing up phlegm, headache, hemoptysis (coughing up blood), and diarrhea. Complications include acute respiratory distress syndrome, acute cardiac injury, and secondary bacterial infections (Huang, 2020). Another health problem that has also emerged in the Covid-19 pandemic is mental health problems which if left unchecked can develop into serious health problems that can last a long time and have the potential to cause a heavy social burden. Currently, the focus of the entire world community for handling the COVID-19 pandemic is aimed at psychosocial factors that will be borne by individuals as a consequence of the pandemic. The public health emergency status established by the world health authorities and followed by the implementation of social restrictions and self-isolation or quarantine as well as limiting community mobility has the potential to have a long-term impact on people's mental health (Gao, 2020) (Pfefferbaum, 2020) (Spoorthy, 2020). Regarding symptoms and mental health decline, the survey found people who are prone to display symptoms related to diseases such as dementia, Alzheimer's, depression, anxiety, psychotic disorders, and changes in brain function. Previous studies in Italy, Germany, and the UK have found that hospitalized Covid-19 patients, mostly women are at higher risk of developing cognitive problems, neurological problems, suffering from PTSD (Post Traumatic Stress Disorder), insomnia, brain fog, confusion, and other related problems for at least 6 months after recovery. The Oxford study shows that people over the age of 50 who are female, and those who are hospitalized due to the coronavirus are much more likely to suffer from brain and psychological complications. Research researchers from the University of Oxford in England also found that the risk of dementia, a brain disorder condition, was much higher in Covid-19 survivors. According to the 
Proceeding The First Muhammadiyah InternasionalPublic Health and Medicine Conference

researchers, these findings are likely to be the same as those of Covid-19 victims worldwide. Researchers say that within three months of testing positive for Covid-19, one in five people who recover is diagnosed with anxiety, depression, or insomnia. Michael Bloomfield, a consultant psychiatrist at University College London and a mental health expert who was not directly involved with the research, said the findings add to growing evidence that COVID-19 can affect the brain and the mind, also increasing the risk of various psychiatric illnesses caused by a combination of psychological stress. associated with the pandemic and the physical effects of the disease. And Simon Wessely, professor of psychiatry at King's College London, said those with mental health disorders were also at a higher risk of contracting Covid-19. Covid-19 affects the central nervous system, and thus may directly increase other disorders. And this study confirms that the risk increases because someone has been infected with Covid-19 before. (Gloria Setyvani Putri, 2021). As one of the sectors most affected by the COVID-19 pandemic, mental health is one of the most neglected areas of public health. Currently, billions of people around the world have been affected by the COVID-19 pandemic, which has adversely affected people's mental health conditions (Saxena, 2016; World Health Organization, 2020a). WHO has identified mental health as an integral component of the response to COVID-19 (World Health Organization, 2020b). Seeing the impact and mental health problems due to the Covid-19 pandemic, the author is interested in research on how the role of government and society in maintaining the mental health of Covid-19 patients in their environment.

\section{METHODS}

This research is a qualitative descriptive study with six research subjects consisting of three men and three women. Subject age between 25-40 years. The subject is Covid-19 survivors. In this study, the researchers took the research location at PT Kimia Farma Diagnostika. Data collection techniques in this study were obtained through interviews and to process data the researchers used qualitative descriptive methods. The author conducted interviews regarding the opinions, views, experiences of the respondents related to the condition of the respondents while undergoing independent isolation. The data from this interview will be processed and reviewed and analyzed based on several references such as books, articles, journals so that they can strengthen the research data.

\section{RESULTS AND DISCUSSION}

The Covid-19 pandemic not only has an impact on physical health but also has an impact on other aspects of life such as the social and economic aspects of the community. These social and economic aspects have a tremendous impact on people's mental health conditions. Government policies that are taken quickly and decisively provide real changes to the social life of the community. Life changes that 
Proceeding The First Muhammadiyah InternasionalPublic Health and Medicine Conference

occur suddenly make it difficult for people to adapt and cause stress to trauma. There is a lot of good information officially issued by the government or hoax news on social media regarding the spread of Covid-19 which can cause unrest and anxiety in the community. Some community groups can receive information and counseling related to PHBS and implement it in their daily lives. Knowing and filtering information correctly related to the prevention and treatment of Covid-19 sufferers.

Based on the results of the author's interview with six Covid-19 survivors, it indicates that Covid19 infection influences mental health conditions for individuals and communities in the neighborhood where they live. From the first subject (woman) at the time of being infected with Covid-19, the subject felt sad, afraid, disappointed why he had to be infected with Covid-19. The subject has three young children who feel sad and worried because they are separated from their families due to self-isolation. Sadly, families who are not infected with Covid-19 are also affected, they get unfavorable treatment from the environment around where they live. The social life experienced by her husband and children greatly affects the emotional condition of the subject so that the subject has experienced mild dementia, the subject forgets what to do, forgets the time, especially remembering prayer times such as carrying out prayer obligations repeatedly.

The second subject also felt sad and anxious because he had to undergo independent isolation and be separated from his mother. This deep sadness was experienced by the subject considering that the subject also recently lost his beloved father due to Covid-19 infection while the mother who was not infected with Covid-19 but was in a sick condition chose to live with relatives in her hometown, while the youngest sister of the subject who was also infected with Covid-19 with symptoms severe enough to be hospitalized, this is what causes the subject to experience sadness and anxiety. The living environment is very supportive both materially and morally on the subject. Good information and understanding from neighbors related to the dangers of the Covid-19 virus, how to prevent and cope if there are residents who are infected with Covid-19 make them able to help and care for each other, sharing and caring shown by RT management and residents greatly strengthens the subject in self-isolation.

The third subject also feels anxiety, this is because the subject does not know if he has been infected with Covid-19 because so far he has never experienced symptoms so that the subject continues to carry out routine activities. The subject feels guilty to his teammates for inadvertently transmitting the viral infection. Subjects who live in boarding houses where the majority of residents are employees from different regions so that interaction and communication are less established. Indifference and do not care about the environment dominate the environment in which he lives. The subject only complains with his family through a call connection and the subject takes care of and fulfills his own needs during the isoman period. The fourth subject was surprised and did not believe because he was infected with Covid-19 and 
Proceeding The First Muhammadiyah InternasionalPublic Health and Medicine Conference

then carried out a follow-up examination so that the results of the examination were truly valid. After receiving his health condition, the subject conveyed to his family and immediately self-isolated. Subjects do not feel sad or depressed because the support from their family and community around the place where they live is very good. The subject is still doing his routine work activities so it looks like he is working from home (WFH).

The fifth subject felt a little sad when symptoms such as loss of taste and sense of smell occurred. The support and support given by the family and the surrounding environment are quite positive so that the subject can rise and be enthusiastic to undergo isomanism and immediately recover to carry out his activities as usual. The person concerned can still carry out his routine work activities. The sixth subject felt a little sad because he took care of his wife who was pregnant and infected with Covid19. But his sadness was not shown because he was worried it would affect his wife's health and emotional condition. The family and living environment provides positive support so that the independent isolation process is carried out well and the wife's pregnancy condition is also safe and after being declared negative the wife immediately gives birth.

From the results of the interview, the authors indicate that individuals infected with Covid-19 experience anxiety, worry, and fear, even stress. Anxiety is not only due to coronavirus infection but also the social environment in which they live which still discriminates against patients and their families infected with Covid-19. After they are declared cured with negative PCR test results, the environment has not fully accepted them, this can hurt the mental development of sufferers, especially for vulnerable groups such as the elderly, women, and children. The anxiety that is still felt by the subjects who do work in health facilities is because the number of Covid-19 sufferers continues to grow and they also cannot know when this pandemic will end. Stigma and discrimination from the community experienced by people with Covid-19 and for medical personnel who relentlessly treat Covid-19 patients are triggers for mental health disorders. In addition, the economic recession that occurs worsens and increases the risk of depression and even suicide. Physical distancing, which until now must still be applied, can change the order of life in society, limit direct communication between communities, limited space for movement and self-actualization stage, this can shackle the soul and stop the process of community creativity. According to Yustinus, self-actualization is an appropriate form or effort to help improve mental health (Yustinus Semiun, 2006). Correct information sourced from official government-owned institutions is very much needed by the community, security and health guarantees for medical personnel in particular and all Indonesian people, in general, can ease the burden on the community. Correct education in the community about prevention and handling if residents- or family members are infected with Covid-19 must always be carried out both through social media, electronics, and in the community's communication environment so 
E-ISSN: 2808-5361 http://e-journal.fkmumj.ac.id/
Proceeding The First Muhammadiyah InternasionalPublic Health and Medicine Conference

that there is no discrimination against residents and families infected with Covid-19. Community participation such as assisting in the form of material and moral support is very much needed by residents who are undergoing independent isolation and families of people with Covid-19. The community always maintains and reminds each other to continue to carry out health protocols in every activity, think positively in responding to any changes that occur. Attention and mutual respect between residents create a feeling of happiness so that it can increase immune and immune responses. The healing process and post-infection recovery can be carried out well.

\section{CONCLUSION AND SUGGESTIONS}

The Covid-19 pandemic that is currently engulfing Indonesia and the world certainly has an impact and changes in the order of life in society, not only physical health status but also mental health. Adaptability, stress management of each individual cannot be generalized. The environment in which you live and the level of understanding about Covid-19 also has an impact on an individual's mental health. The participation and positive response of the community greatly affect the mental health of people with Covid-19.

The role of the government, non-government organizations (NGOs) related to the handling of the Covid-19 pandemic in educating the public is very much needed, preventive steps need to be taken to overcome mental health problems that occur due to the Covid-19 pandemic. Recovery of the economic condition of the community, it is necessary to get used to paying attention to hygiene, sanitation, physical health, and mental health of individuals and families and not to consider it taboo to seek help from experts/professionals in their fields This is still a homework that must be carried out not only by the government but all of us as Indonesian citizens.

\section{REFERENCES}

Aula Chasina Achmad. (2019). Paradigma Kesehatan Mental. Unair News.

Data Infeksi Covid -19. (2021). JHU CSSE Covid -19 data.

Dr. Sandu Siyoto, SKM., M. K., \& M.Ali Sodik, M. (2015). Dasar Metodologi Penelitian (Ayup (Ed.); 1st ed.). Literasi Media.

Gao, J. et. a. (2020). Mental Health Problems and social media exposure during the covid-19 outbreak. Plos One.

Gloria Setyvani Putri. (2020). WHO Resmi Sebut Virus Corona Covid-19 sebagai Pandemi Global. https://www.kompas.com/sains/read/2020/0 3/12/083129823/who-resmi-sebut-virus- coronacovid-19-sebagai-pandemi-global?page=all. 
E-ISSN: 2808-5361 http://e-journal.fkmumj.ac.id/
Proceeding The First Muhammadiyah InternasionalPublic Health and Medicine Conference

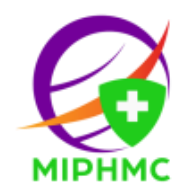

Huang, C. et. a. (2020). Clinical features of patients infected with 2019 Novel Corona Virus in Wuhan, China. The Lancet,395(10223), 497-506. https://doi.org/10.1016/s0140- 6736(20)30183-5

KemKes. (2018). Pengertian Kesehatan mental. Kemkes, Dir.Promkes Dan Pemberdayaan Masyarakat. https://promkes.kemkes.go.id/

Pfefferbaum, B. et. a. (2020). Mental Health and the Covid-19 pandemic. New England Journal of Medicine, 383(6).

Siti Nurjanah. (2020). Gangguan Mental Emosional Pada Klien Pandemi Covid 19 di Rumah Karantina. Jurnal Ilmu Keperawatan Jiwa, 3. https://doi.org/329-334

Spoorthy, M. S. et. a. (2020). Mental Health Problems faced by Healthcare workers due to the Covid-19 pandemic. Asian Journal of Psychiatry, 51.

UU No 36. (2009). Undang - Undang Kesehatan. 27(7).

Yustinus Semiun. (2006). Kesehatan Mental 3. Kanisius. 
Volume I Tahun 2021

November 2021
E-ISSN: 2808-5361

http://e-journal.fkmumj.ac.id/
Proceeding The First Muhammadiyah InternasionalPublic Health and Medicine Conference

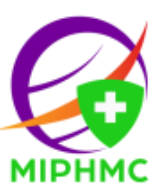

